\title{
PENYERAPAN ION LOGAM Cu(II) MENGGUNAKAN ECENG GONDOK (Eichhornia crassipes) SECARA FITOREMEDIASI
}

\author{
Intan Lestari ${ }^{1}$, Shinta Putri Ayu ${ }^{1}$, Ngatijo $^{1 *}$ \\ ${ }^{1}$ Program Studi Kimia, Fakultas Sains dan Teknologi Universitas Jambi \\ Jln. Raya Jambi-Ma. Bulian KM 15 Mendalo Indah, Jambi \\ ngatijo@unja.ac.id
}

\begin{tabular}{l}
\hline Artikel Info \\
Diterima \\
tanggal \\
21.01 .2021 \\
Disetujui \\
publikasi \\
tanggal \\
30.04.2021 \\
Kata kunci : \\
Phytoremediat \\
ion, Cu(II) Ion, \\
Adsorption, \\
Eceng Gondok \\
\end{tabular}

$\underline{\text { Artikel Info }}$

Diterima

tanggal

21.01.2021

Disetujui

publikasi

tanggal

30.04 .2021

Kata kunci :

Phytoremediat

ion, $\mathrm{Cu}(\mathrm{II}) \mathrm{Ion}$,

Adsorption,

Eceng Gondok

\begin{abstract}
ABSTRAK
Fitoremediasi adalah penggunaan tanaman dan proses tanaman untuk menghilangkan, menurunkan atau membuat bahan berbahaya tidak berbahaya bahan yang ada di tanah atau air tanah. Fitoremediasi dapat digunakan untuk stabilisasi polutan, ekstraksi, degradasi atau penguapan. Penelitian ini bertujuan untuk penyerapan ion logam $\mathrm{Cu}$ (II) menggunakan Eceng Gondok secara fitoremediasi. Parameter penyerapan yang dipelajari adalah variasi $\mathrm{pH}$, konsentrasi ion logam $\mathrm{Cu}(\mathrm{II})$, waktu kontak tanaman di dalam media. Hasil penelitian menunjukkan bahwa variasi kondisi $\mathrm{pH}$ larutan memberikan penyerapan optimum pada $\mathrm{pH} 4$ dengan efisiensi adsorpsi 98,6\%. Sedangkan variasi konsentrasi larutan memberikan penyerapan optimum pada konsentrasi 500 ppm dengan efisiensi adsorpsi 99,392\%. Lama waktu kontak memberikan penyerapan optimum pada hari ke-5 dengan efisiensi adsorpsi 99,62\%. Berdasarkan data karakterisasi FTIR menunjukan bahwa Eceng Gondok memiliki gugus fungsi hidroksil, karbonil, karboksil, dan amina yang berfungsi sebagai gugus aktif untuk proses adsorpsi ion logam $\mathrm{Cu}$ (II) oleh Eceng Gondok (Eichornia crassipes).
\end{abstract}

\section{ABSTRACT}

Phytoremediation is the use of plant and plant processes to remove, reduce or render harmless, harmless materials that are in soil or groundwater. Phytoremediation can be used for pollutant stabilization, extraction, degradation or evaporation. This study aims to adsorption of $\mathrm{Cu}$ (II) metal ions using water hyacinth by phytoremediation. The adsorption parameters studied were $\mathrm{pH}, \mathrm{Cu}$ (II) ion concentration, plant contact time in the media. The results showed that variations in the $\mathrm{pH}$ of the solution provided optimum adsorption at $\mathrm{pH} 4$ with an adsorption efficiency of $98.6 \%$. While the variation in solution concentration provides optimum adsorption at a concentration of $500 \mathrm{ppm}$ with an adsorption efficiency of $99.392 \%$. The duration of contact provides optimum absorption on the 5th day with an adsorption efficiency of $99.62 \%$. Based on FTIR characterization data, it shows that water hyacinth has hydroxyl, carbonyl, carboxyl, and amine functional groups which function as active groups for the adsorption process of $\mathrm{Cu}$ (II) metal ions by water hyacinth (Eichornia crassipes). 


\section{PENDAHULUAN}

Fitoremediasi adalah penggunaan tanaman dan proses tanaman untuk menghilangkan, menurunkan atau membuat bahan berbahaya tidak berbahaya bahan yang ada di tanah atau air tanah (Putra et al, 2016). Teknologi ini bersifat non-intrusif, relatif murah dan aman untuk teknik pembersihan air secara konvensional. Eceng Gondok (Eichornia crassipe.) dipilih sebagai tanaman uji dalam penelitian ini karena dapat meningkatkan aktivitas mikroba, menyerap nutrisi dan menghilangkan padatan tersuspensi. Kemampuan tanaman ini untuk mengolah unsur hara dari limbah menjadi penting phytomass ditambahkan untuk memperburuk ketidakseimbangan suplai nutrisi yang timbul selama percobaan dan menjadikannya salah satu tanaman yang paling cocok untuk digunakan dalam fitoremediasi air limbah (Sarkar et al, 2015 dan Sarkar et al, 2016). Namun, aplikasinya adalah terbatas pada kontaminasi permukaan saja, karena kedalaman pembersihan sangat ditentukan oleh panjang tanaman akar. Teknologi ini bersifat pasif terkait pengangkutan kontaminan, pergerakan kontaminan di dalam air diinduksi secara eksklusif oleh hisap akar tanaman yang lambat dan dengan demikian, efisiensi penghilangan kontaminan bergantung pada perpanjangan akar tanaman di permukaan air (Ahmed et al, 2016 dan Blazquez et al, 2005). Dalam proses fitoremediasi polutan dikumpulkan pada suatu jaringan dan didekomposisikan menjadi bentuk yang tidak berbahaya atau ditimbun pada jaringan tanaman. Banyak tumbuhan yang dapat menyerap logam berat dan disebut sebagai tumbuhan hiperakumulator seperti Eceng Gondok, kiambang, Anturium Merah/ Kuning, Alamanda Kuning/Ungu, Akar Wangi, Bambu Air, Cana Presiden Merah/Kuning/Putih, Dahlia, Dracenia Merah/Hijau, Heleconia Kuning/ Merah, Jaka, Keladi Loreng/Hitam, Lotus Kuning/ Merah, Padi-padian, Papirus, Pisang Mas, Spider Lili, dan lainnya yang banyak ditemukan di daerah persawahan dan genangan air (Irhamni, et al., 2017).

Tanaman Eceng Gondok merupakan tanaman yang sangat potensial untuk digunakan sebagai adsorben logam berat, baik pada wilayah perairan ataupun pada limbah-limbah sisa industri. Eceng Gondok dapat menurunkan kadar logam $\mathrm{Fe}, \mathrm{Pb}$, dan $\mathrm{Cu}$ pada limbah elektroplating, kandungan unsur logam optimal dari variasi waktu perendaman dari hasil SEM-EDS menunjukkan kadar logam Fe sebesar 2,453\% pada waktu perendaman 60 menit 
dibandingkan dengan logam $\mathrm{Cu}$, dan $\mathrm{Pb}$. Eceng Gondok dapat digunakan sebagai adsorben ion kalsium dengan bantuan regenerasi $\mathrm{HCl}$ yang akan meningkatkan laju adsorpsi ion kalsium. Penelitian ini bertujuan untuk mengetahui potensi penyerapan tanaman Eceng Gondok (Eichornia crassipes) terhadap ion logam $\mathrm{Cu}(\mathrm{II})$ secara fitoremediasi. Parameter yang digunakan dalam penelitian ini yaitu pengaruh $\mathrm{pH}$ media, pengaruh konsentrasi logam, dan lama waktu kontak.

\section{METODE}

\section{Alat dan Bahan}

Alat-alat yang digunakan dalam penelitian ini adalah akuarium ukuran $20 \mathrm{~cm}$ x $20 \mathrm{~cm}$ x $20 \mathrm{~cm}, \mathrm{pH}$ indikator, neraca analitik, gelas beker $25 \mathrm{ml}$, gelas ukur $25 \mathrm{ml}$, pipet tetes, labu ukur $250 \mathrm{ml}$, kertas saring, gelas beker $50 \mathrm{ml}$, pisau, mortar dan alu, labu ukur $50 \mathrm{ml}$, Spektroskopi Serapan Atom (SSA), Fourier Transform Infra Red (FTIR). Bahan-bahan yang digunakan pada penelitian ini adalah Eceng Gondok (Eichornia crassipes) (Mart.) Solms), pupuk TSP, air, $\mathrm{CuSO}_{4} .5 \mathrm{H}_{2} \mathrm{O}, \mathrm{HNO}_{3}$ pekat, akuades, $\mathrm{HCl} 1 \mathrm{M}, \mathrm{NaOH} 1 \mathrm{M}$.

\section{Prosedur Percobaan}

\section{Persiapan Tanaman Eceng Gondok (Eichornia crassipes).}

Persiapan Tanaman Eceng Gondok (Eichornia crassipes). Tanaman Eceng Gondok (Eichornia crassipes) yang digunakan dalam penelitian ini diperoleh dari kolam di daerah Muaro Jambi. Tanaman ini diambil seluruh organ tubuhnya meliputi akar, batang dan daun.

\section{Aklimatisasi Tanaman Eceng Gondok}

Aklimatisasi tanaman Eceng Gondok didahului dengan mencuci akar Eceng Gondok sehingga bersih dari lumpur dan kandungan senyawa kimia lainnya. Selanjutnya menumbuhkan tanaman dalam air (golongan B/ air baku air minum) di dalam akuarium (20 $\mathrm{cm}$ x $20 \mathrm{~cm}$ x $20 \mathrm{~cm}$ ) selama 7 hari dan ditambahkan nutrisi yaitu pupuk TSP (2 gram/ $200 \mathrm{~g}$ Eceng Gondok). Selanjutnya ditumbuhkan lagi selama 7 hari. 


\section{Penentuan Konsentrasi Ion Cu(II) Optimum}

Sebanyak 1 liter air dimasukan ke dalam masing-masing akuarium. Kondisi pH optimum diatur pada masing-masing larutan. Ditambahkan larutan $\mathrm{Cu}$ (II) dengan variasi konsentrasi 12,5; 25; 37,5; dan 50 ppm. Kemudian dimasukkan tanaman Eceng Gondok ke dalam masingmasing media dan diamkan selama 7 hari. Konsentrasi ion logam $\mathrm{Cu}(\mathrm{II})$ dalam masing-masing media diukur dengan SSA. Parameter pH mediasi larutan dipelajari pada pH 3-7, waktu kontak dipelajari dengan memvariasikan waktu kontak selama 5,10,15 dan 20 hari.

\section{Karakterisasi Tanaman Eceng Gondok (Eichornia crassipes) Sebelum dan Setelah Fitoremediasi.}

Sampel tanaman Eceng Gondok sebelum dan setelah fitoremediasi dicuci terlebih dahulu sampai bersih dan di potong kecil-kecil. Selanjutnya sampel dikeringkan di bawah sinar matahari hingga benar-benar kering, kemudian digerus hingga halus. Sampel kemudian dianalisa menggunakan spektroskopi FTIR.

\section{HASIL DAN PEMBAHASAN}

Proses aklimatisasi dilakukan untuk meyesuaikan tanaman Eceng Gondok dengan lingkungan hidupnya yang baru. Aklimatisasi dilakukan didalam akuarium berukuran 20 x 20 x $20 \mathrm{~cm}$ yang berisi $1 \mathrm{~L}$ air bersih yang mengandung 2 gram pupuk TSP/200 gram Eceng Gondok pada masing-masing akuarium. Penambahan pupuk TSP dilakukan untuk memberikan nutrisi pada tanaman Eceng Gondok. Proses aklimatisasi dilakukan selama 7 hari yang selanjutnya akan digunakan untuk penentuan kondisi $\mathrm{pH}$, konsentrasi, dan waktu kontak optimum. Hasil aklimatisasi tanaman Eceng Gondok dapat dilihat pada Gambar 1.

Setelah dilakukan proses aklimatisasi, warna daun Eceng Gondok mengalami perubahan menjadi hijau tua dan tanaman Eceng Gondok terlihat lebih segar. Penambahan pupuk TSP memberikan efek pada pertumbuhan daun. Selain itu, pertumbuhan Eceng Gondok selama proses aklimatisasi tidak memberikan dampak yang terlalu besar pada penambahan panjang batang/tanaman Eceng Gondok. Pertumbuhan Eceng Gondok selama aklimatisasi terlihat dari penambahan panjang akar tanaman tersebut dan terlihat bahwa akar tanaman Eceng Gondok 
semakin lebat/banyak setelah dilakukan proses aklimatisasi. Tanaman Eceng Gondok yang telah diaklimatisasi selanjutnya digunakan untuk penentuan kondisi optimum fitoremediasi ion logam $\mathrm{Cu}(\mathrm{II})$.

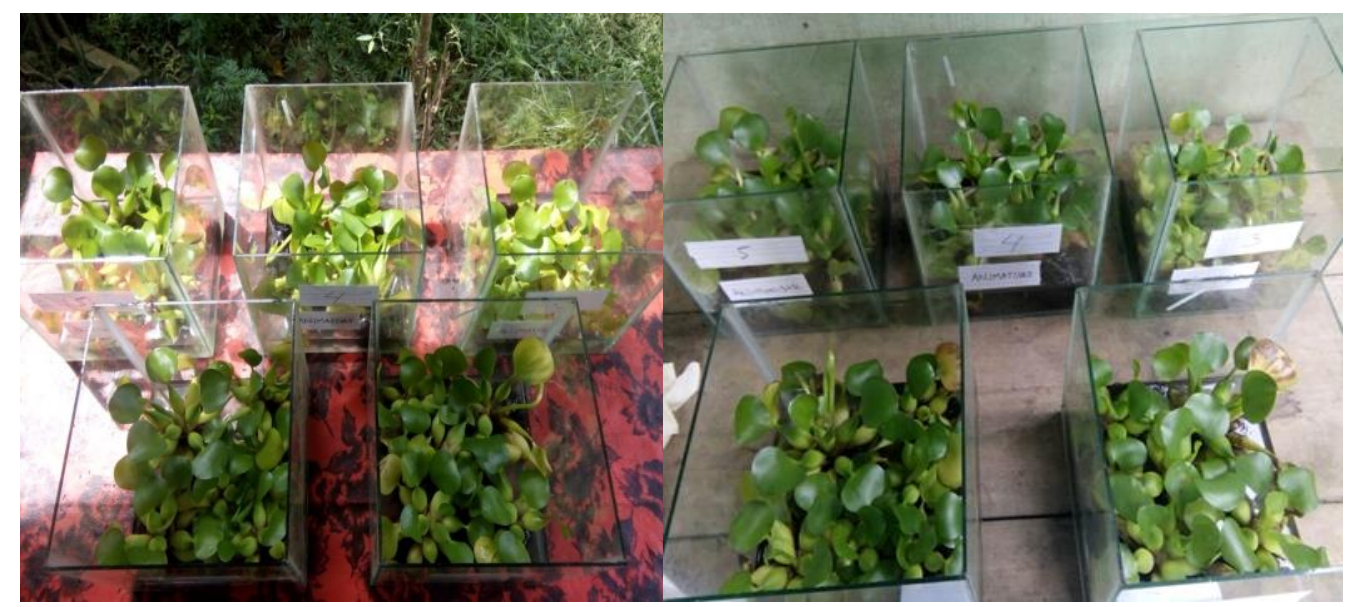

Gambar 1. Aklimatisasi Eceng Gondok dalam aquarium.

\section{Penentuan Kondisi pH Optimum}

Penentuan kondisi $\mathrm{pH}$ optimum dilakukan dengan menambahkan berbagai variasi $\mathrm{pH}$ yaitu pada pH 3-7 dengan konsentrasi ion $\mathrm{Cu}$ (II) 2,5 mg/L dan berat basah Eceng Gondok $200 \mathrm{~g}$ selama 7 hari. Hasil pengaruh $\mathrm{pH}$ terhadap penyerapan ion $\mathrm{Cu}$ dapat dilihat pada Gambar 2.

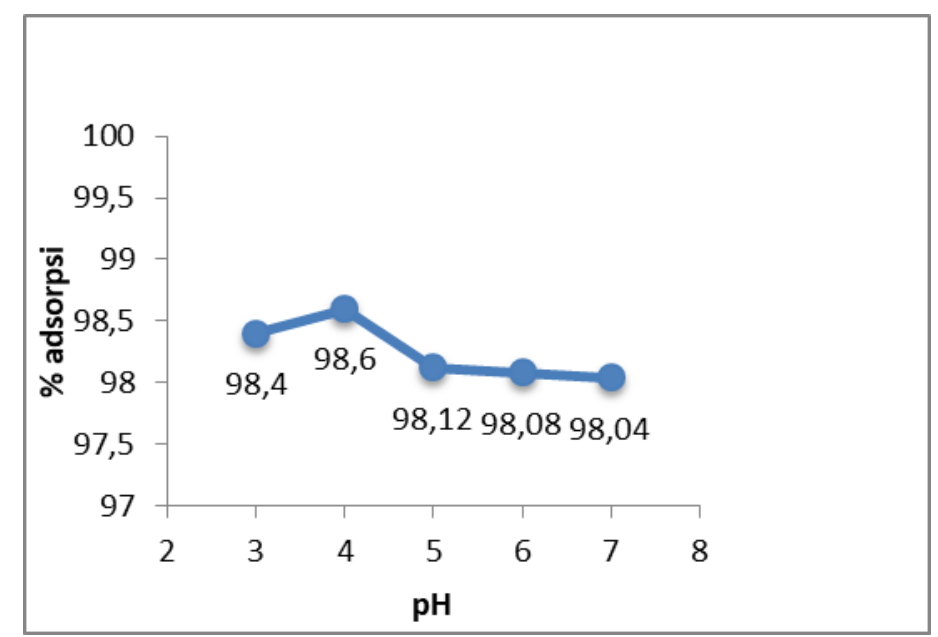

Gambar 2. Pengaruh pH Larutan Terhadap Efisiensi Adsorpsi ion $\mathrm{Cu}(\mathrm{II})$. 
Penyerapan terjadi pada pH 4 dengan efesiensi penyerapan sebesar 98,6\%. Shofiyani dan gusrizal (2006) melaporkan bahwa adsorpsi Cu(II) menggunakan biomassa Eceng Gondok (Eichornia Crassipes) memberikan penyerapan optimum pada $\mathrm{pH} 5-6$, terikatnya spesies $\mathrm{Cu}$ (II) diperkirakan terjadi melalui interaksi elektrostatik dan pembentukan kompleks antara $\mathrm{Cu}^{2+}$ dengan situs aktif Eceng Gondok. Perbedaan hasil penyerapan pada $\mathrm{pH}$ 3,4,5,6, dan 7 terjadi karena pada $\mathrm{pH} 4$ (konsentrasi ion $\mathrm{H}^{+}$semakin kecil) kompetisi antara ion $\mathrm{H}^{+}$dan logam makin berkurang sehingga jumlah logam teradsorpsi makin besar dibanding dengan $\mathrm{pH}$ 3 (Tangio, 2013). Sedangkan pada pH yang lebih tinggi yaitu pH 5, 6 dan 7 terjadi penurunan yang diduga terjadi karena adanya pembentukan $\mathrm{Cu}(\mathrm{OH})_{2}$ (Lelifajri, 2010) dan kondisi $\mathrm{pH}$ yang semakin tinggi menyebabkan larutan bersifat basa sehingga kelarutan $\mathrm{Cu}$ semakin kecil dan mulai terjadi pengendapan. Hal ini memungkinkan $\mathrm{Cu}$ yang terserap semakin sedikit (Tangio, 2013).

\section{Penentuan Konsentrasi Optimum}

Berdasarkan data hasil pengujian konsentrasi ion $\operatorname{logam} \mathrm{Cu}$, terlihat bahwa konsentrasi ion logam $\mathrm{Cu}$ yang tertinggal dalam setiap sampel air pada masing-masing akuarium memiliki nilai yang lebih kecil, diperkirakan bahwa tanaman Eceng Gondok telah menyerap sebagian ion logam $\mathrm{Cu}$ di dalam media air tersebut. Dalam penelitian ini digunakan variasi konsentrasi ion logam $\mathrm{Cu}$ sebesar 12,5 ppm, 25 ppm, 37,5 ppm, dan 50 ppm. Data hasil pengujian menunjukkan bahwa tanaman Eceng Gondok telah berperan nyata dalam menyerap ion logam berat $\mathrm{Cu}$ seperti disajikan pada grafik berikut.

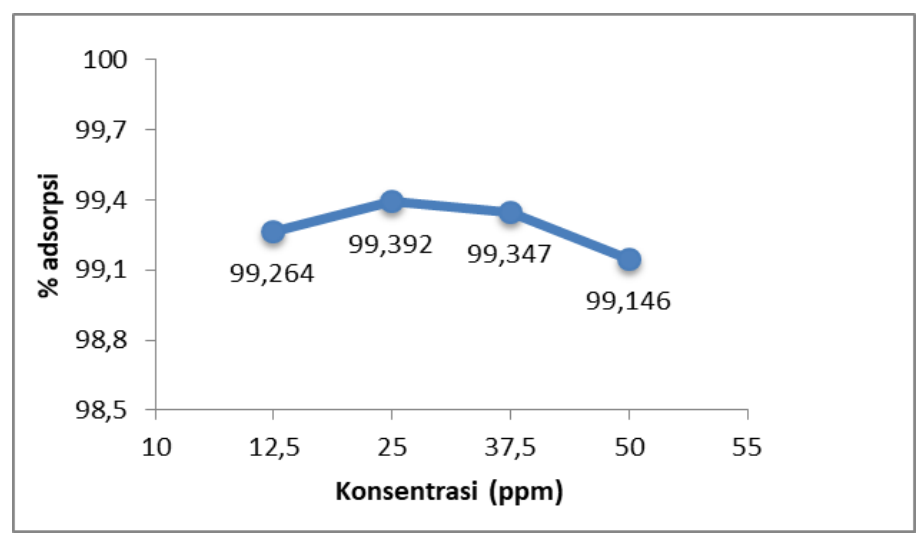

Gambar 3. Grafik hubungan konsentrasi ion logam $\mathrm{Cu}(\mathrm{II})$ terhadap efisiensi adsorpsi Eceng Gondok. 
Berdasarkan Gambar 3 dapat dilihat bahwa penyerapan ion logam $\mathrm{Cu}(\mathrm{II})$ dalam 200 Eceng Gondok selama 7 hari mampu menurunkan konsentrasi ion logam $\mathrm{Cu}$ (II) di dalam media air. Hampir seluruh ion logam $\mathrm{Cu}(\mathrm{II})$ dalam media air diserap oleh tanaman Eceng Gondok, dengan efisiensi adsorpsi diperoleh pada konsentrasi 12,5 ppm mampu menyerap sebesar 99,264\%, pada 25 ppm sebesar 99,392\%, pada 37,5 ppm sebesar 99,347\%, dan pada 50 ppm sebesar 99,146\%. Hal ini mengindikasikan bahwa telah terjadi pemindahan ion logam $\mathrm{Cu}(\mathrm{II})$ dari media air ke tanaman Eceng Gondok. Penurunan nilai efisiensi adsorpsi pada konsentrasi 37,5-50 ppm.

Menurut Irhamni, et al (2017) penyerapan dan akumulai logam berat oleh tumbuhan dapat dibagi menjadi tiga proses yang sinambung, yaitu penyerapan logam oleh akar, translokasi logam dari akar ke bagian tumbuhan lain, dan lokalisasi logam pada bagian sel tertentu untuk menjaga agar tidak menghambat metabolisme tumbuhan tersebut. Agar tumbuhan dapat menyerap logam, maka logam harus dibawa ke dalam larutan di sekitar akar (rizosfer) dengan beberapa cara bergantung pada spesies tumbuhannya. Setelah logam dibawa masuk ke dalam sel akar, selanjutnya logam harus diangkut melalui jaringan pengangkut, yaitu xilem dan floem, ke bagian tumbuhan lain. Untuk meningkatkan efisiensi pengangkutan, logam diikat oleh molekul khelat. Berbagai molekul khelat yang berfungsi mengikat logam dihasilkan oleh tumbuhan. Untuk mencegah peracunan logam terhadap sel, tumbuhan mempunyai mekanisme detoksifikasi, misalnya dengan menimbun logam di dalam organ tertentu seperti akar.

\section{Penentuan Waktu Kontak Optimum}

Waktu kontak memiliki peranan yang sangat kuat dalam proses fitoremediasi. Lamanya waktu kontak antara tanaman dan ion logam yang diserap akan menentukan seberapa besar kemampuan tanaman tersebut untuk menyerap logam berat. Setiap tanaman memiliki kemampuan yang berbeda dalam menyerap ion logam berat, proses penyerapan ini akan mencapai batas optimum pada waktu tertentu dan akan turun kembali.

Penentuan waktu kontak optimum dilakukan dengan variasi 5, 10, 15, dan 20 hari. Efisiensi adsorpsi tertinggi didapatkan pada hari ke-5 yaitu sebesar 99,62\% seperti tertera pada Gambar 4. 


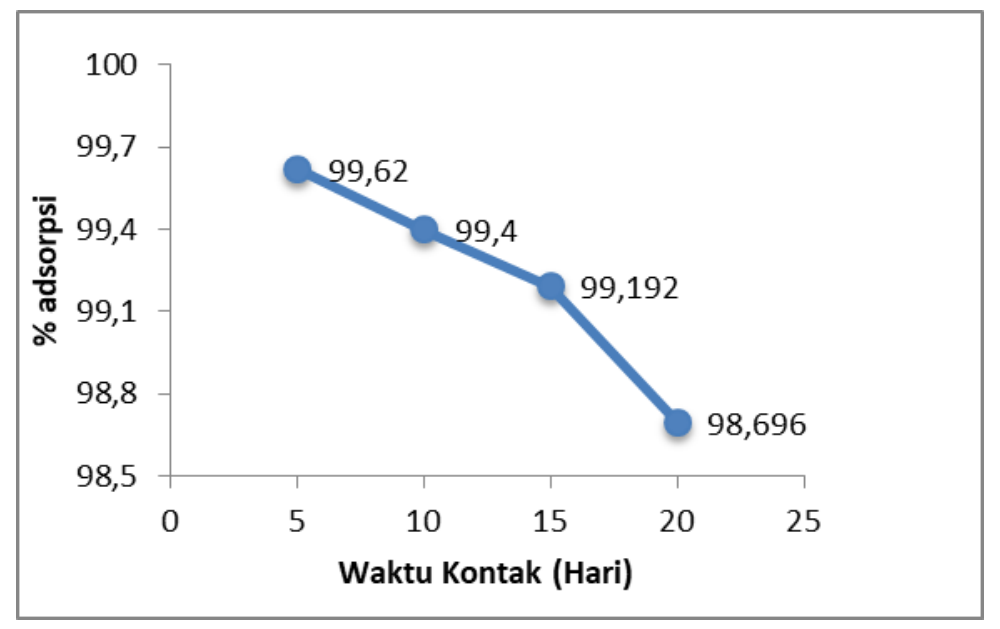

Gambar 4. Pengaruh waktu kontak terhadap efisiensi adsorpsi oleh Eceng Gondok.

Dari Gambar 4 dapat dilihat bahwa efisiensi adsorpsi semakin menurun seiring dengan bertambahnya lama waktu kontak antara tanaman Eceng Gondok dengan ion logam $\mathrm{Cu}(\mathrm{II}) \mathrm{di}$ dalam media. Pada waktu kontak 10 hari efisiensi adsoprsi menurun pada 99,4\%, pada waktu kontak 15 hari menurun pada 99,192\%, dan menurun drastis pada waktu kontak 20 hari yaitu pada 98,696\% atau mengalami penurunan sebesar 0,496\% dari efisiensi adsoprsi pada hari ke 15. Penurunan efisiensi adsorpsi pada tanaman Eceng Gondok disebabkan karena adanya proses desorpsi, yaitu proses pelepasan kembali ion logam berat yang telah diserap karena menurunnya kemampuan tanaman tersebut untuk menyerap ion logam berat. Lelifajri (2010) menyatakan bahwa desorpsi merupakan salah satu fenomena dalam adsoprsi fisika yang menyatakan bahwa proses adsorpsi bersifat reversibel.

Djo, et al. (2017) juga menyatakan bahwa semakin lama waktu kontak antara tanaman Eceng Gondok dengan ion logam $\mathrm{Cu}$ (II) dapat menurunkan konsentrasi ion logam $\mathrm{Cu}(\mathrm{II})$ hingga $0,111 \mathrm{mg} / \mathrm{L}$ pada hari ke-14, dalam penelitiannya mengenai fitoremediasi menggunakan tanaman Eceng Gondok (Eichornia Crassipes) untuk menurunkan COD dan kandungan $\mathrm{Cu}(\mathrm{II})$ dan $\mathrm{Cr}(\mathrm{VI})$ limbah cair laboratorium analitik Universitas Udayana. Djo, et al (2017) menyatakan bahwa rendahnya kadar ion $\mathrm{Cu}$ pada hari ke-14 disebabkan karena sebagian ion logam $\mathrm{Cu}$ telah diserp oleh tanaman Eceng Gondok. 


\section{Karakterisasi Tanaman Eceng Gondok Sebelum dan Setelah Fitoremediasi dengan FTIR}

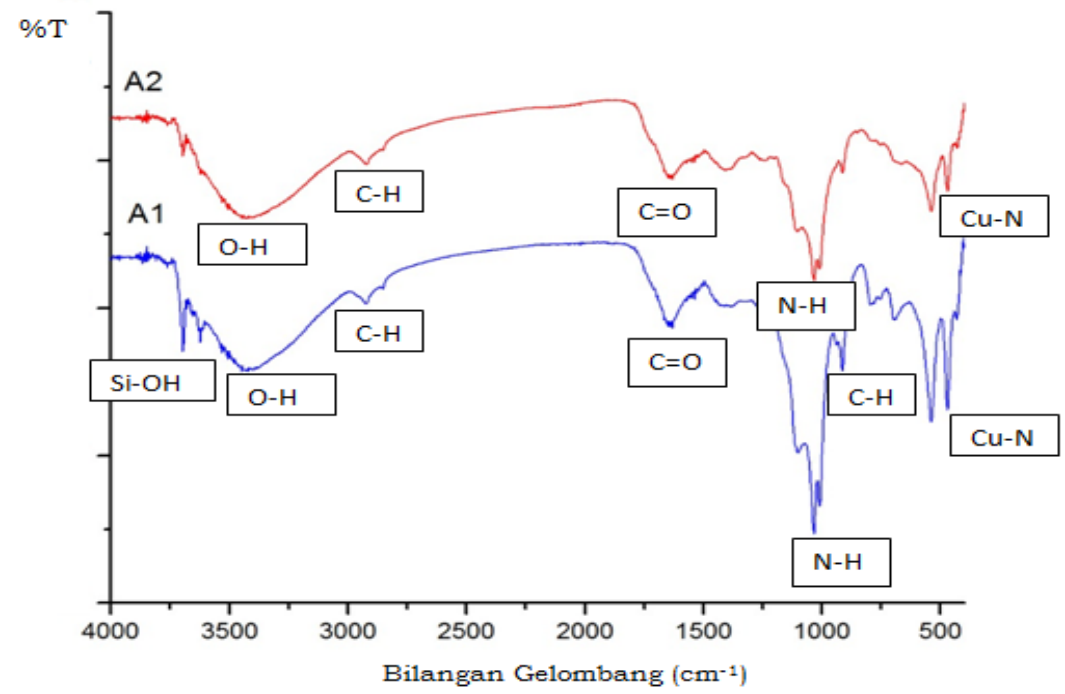

Gambar 5. Spektra FTIR Akar Eceng Gondok Sebelum (A1) dan Setelah (A2) Fitoremediasi.

Hasil spektra IR bagian akar Eceng Gondok sebelum dan setelah fitoremediasi dapat dilihat pada Gambar 5. Pada Gambar 5 dapat dilihat bahwa kedua spektra ini memiliki perbedaan yaitu adanya gugus silika pada akar Eceng Gondok sebelum proses fitoremediasi (spektra A1) pada bilangan gelombang 3622,44 $\mathrm{cm}^{-1}$ dan $3695,73 \mathrm{~cm}^{-1}$ yang merupakan vibrasi ulur O-H dari gugus silanol $(\mathrm{Si}-\mathrm{OH})$. Adanya serapan gugus silanol ( $\mathrm{Si}-\mathrm{OH})$ pada spektra A1 diduga berasal dari serapan akar Eceng Gondok terhadap sedimen lumpur pada saat penumbuhan tanaman. Selanjutnya kedua spektra ini memberikan serapan gugus fungsi yang sama pada bagian akar sebelum dan setelah fitoremediasi. Tumbuhan dapat menyerap zat dari lingkungannya dengan menunjukan selektifitas tertentu. Zat yang diserap oleh jaringan tanaman dapat melalui daun (stomata) atau akar. Pada akar, zat masuk ke dalam sel dengan cara difusi baik difusi aktif maupun difusi pasif (Nur F, 2013).

\section{KESIMPULAN}

Tanaman Eceng Gondok (Eichornia Crassipes) mampu menyerap ion logam berat $\mathrm{Cu}$ (II) dari media air secara fitoremediasi. Penyerapan optimum diperoleh pada kondisi konsentrasi 25 ppm dengan pH 4 dan waktu kontak 5 hari dengan efisiensi adsorpsi sebesar 
99,62\%. Fitoremediasi ion logam $\mathrm{Cu}(\mathrm{II})$ pada Eceng Gondok dapat dilakukan karena Eceng

Gondok mengandung gugus fungsi seperti hidroksil, karbonil, karboksil, dan amina yang berfungsi sebagai gugus aktif untuk proses adsorpsi ion logam $\mathrm{Cu}(\mathrm{II})$.

\section{DAFTAR PUSTAKA}

Ahmed, K.S., Rahman, A.K.M.L., Sarkar, M., Islam, J.B., Jahan, I.A., Moniruzzaman, M., Saha, B., Bhoumik, N.C., 2016, Assessment on the level of contam ination of Turag river at Tongi area in Dhaka, Bangladesh, J. Sci. Ind. Res., 51 (3), 193-202.

Blazquez, A., Martin,M.A., Lara, M.C., R. Marti, R., Campos, Y., Cabello, A., Garesse, R., Bautista, Andreu, A.L., Arenas, J., 2005, Removal of cadmium ions with olive stones: the effect of some parameters, Process Biochem., 40 (8), 2649-2654.

Djo, Y.H.W., Suastuti, D.A., Iryanti E., Suprihatin, Sulihingtyas. W.D., 2017, Cakra Kimia. Fitoremediasi Menggunakan Tanaman Eceng Gondok (Eichornia Crassipes) Untuk Menurunkan COD dan Kandungan $\mathrm{Cu}$ dan $\mathrm{Cr}$ Limbah Cair Laboratorium Analitik Universitas Udayana, Program Studi kimia FMIPA Universitas Udayana, Bali.

Irhamni., Setiyati Pandia., Edison Purba., dan Wirsal Hasan., 2017, Kajian Akumulator Beberapa Tumbuhan Air Dalam Menyerap Logam Berat Secara Fitoremediasi, Universitas Serambi Mekah, Banda Aceh.

Lelifajri., 2010, Adsorpsi Ion Logam Cu(II) Menggunakan Lignin Dari Limbah Serbuk Kayu Gergaji, Jurnal Rekayasa Kimia dan Lingkungan.

Nur, F., 2013, Fitoremediasi logam berat cadmium, Biogenensis., Vol 1, No 1, 74-83.

Putra, R.S., Novarita, D., and Cahyana, F., 2016, Water Hyacinth (Eichornia crassipes (Mart.) Solms] with Electro-Assisted Phytoremediation (EAPR), AIP Conference Proceedings., 1744, 020052.

Sarkar, M., Rahman, A.K.M.L., Islam, J.B., Ahmed, K.S., Uddin, M.N., Bhoumik, N.C., 2015, Study of hydrochemistry and pollution status of Buriganga river, Bangladesh, Bangladesh, J. Sci. Ind. Res., 50 (2), 123-134.

Sarkar, M., Islam, J.B., Akter, S., 2016, Pollution and ecological risk assessment for the environmentally impacted Turag river, Bangladesh, J, Mater. Environ. Sci., 7 (7), 22952304

Tangio, Julhim S., 2013, Adsorpsi Logam Timbal (Pb) Dengan Menggunakan Biomassa Eceng Gondok (Eichornia crassipes), Jurnal Entropi. 